\title{
Intussusception in an adult with cystic fibrosis successfully reduced with contrast enema
}

\author{
Morten Thorsteinsson, Stefan Kobbelgaard Burgdorf, Luit Penninga
}

Department of Surgical Gastroenterology and Transplantation, Rigshospitalet Copenhagen University Hospital, Copenhagen, Denmark

\section{Correspondence to Dr Luit Penninga, LP@ctu.dk}

Accepted 21 June 2015
CrossMark

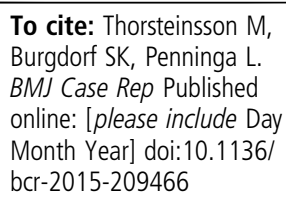

\section{DESCRIPTION}

A 34-year-old woman with cystic fibrosis and diabetes mellitus type I was admitted with a 1-week history of intermittent pain localised to the lower right quadrant of the abdomen. She presented with mild diarrhoea, but no nausea or vomiting. She had no history of prior abdominal surgery. On clinical examination, the abdomen was soft with local tenderness in the lower right quadrant and active bowel sounds. There was no palpable mass. Blood test analysis showed a white cell count of $6.8 \times 10^{9} /$ $\mathrm{L}$ and $\mathrm{C}$ reactive protein $5 \mathrm{mg} / \mathrm{L}$. The forced expiratory volume in $1 \mathrm{~s}$ was $35 \%$. A plain radiograph of the abdomen was normal. The initial suspicion was appendicitis and the patient was observed overnight. Because her symptoms failed to resolve over the following days, she underwent an abdominal CT scan. The CT imaging showed a colocolic intussusception with caecum and appendix placed in the transverse colon, with thickening and oedema of the ascending colon (figure 1). The patient was treated with a water-soluble contrast enema and the intussusception was successfully reduced (figures 2 and 3). She had instant relief of symptoms and was discharged the following day. Three weeks later, a colonoscopy showed no sign of malignancy or pathological leadpoints.

Intussusception occurs when a segment of bowel invaginates into the lumen of an adjacent bowel segment. ${ }^{1}$ Patients with cystic fibrosis have an increased risk of colonic disorders, including intussusception. ${ }^{2}$ The non-operative management with air or contrast enema is typically the first choice of treatment in children, but less well documented in

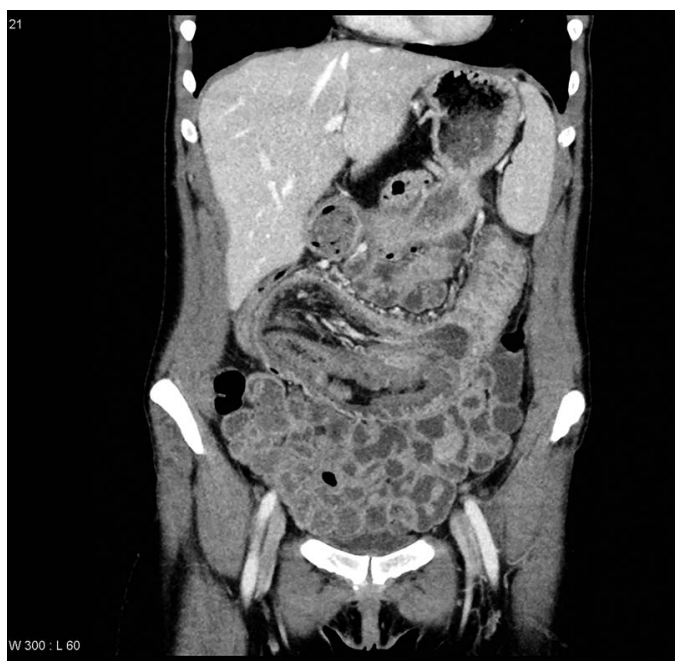

Figure 1 CT imaging of the abdomen showing caecum and appendix invaginated into the transverse colon.

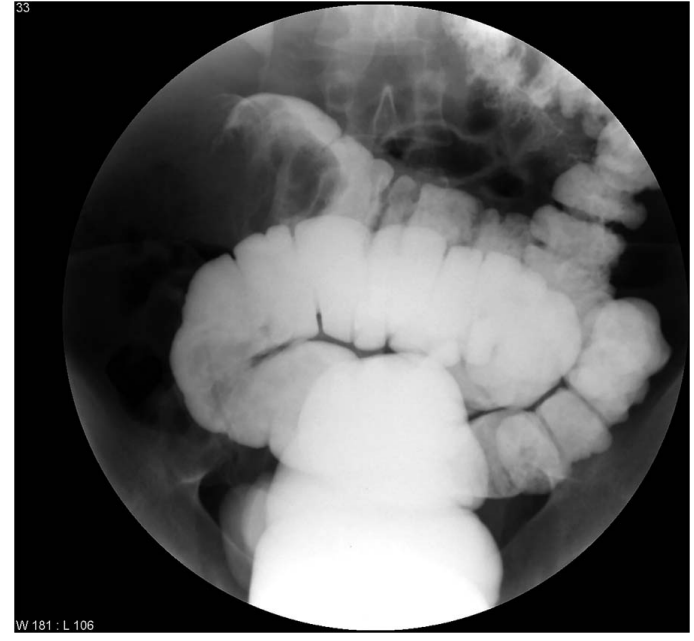

Figure 2 X-ray of the colon and rectum with contrast enema, demonstrating the intussusception in the transverse colon.

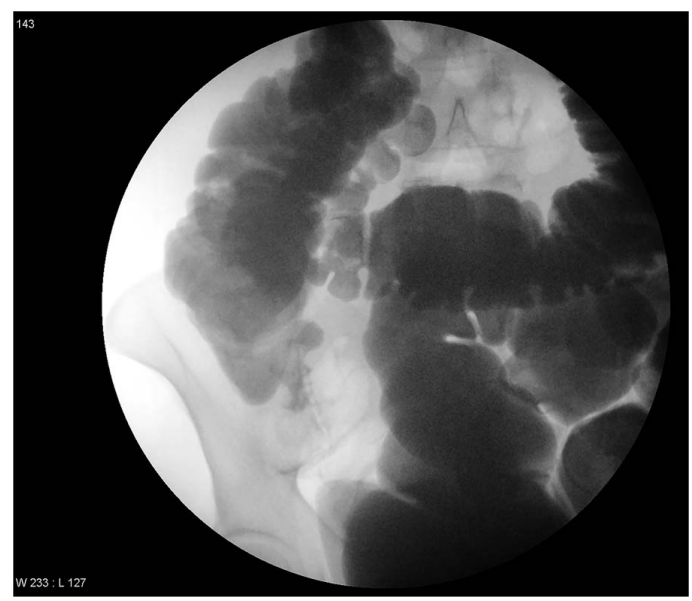

Figure 3 X-ray of the colon after reduction of the intussusception, where the contrast enema fills the small intestine.

adults because of the rare presentation. ${ }^{3}$ Our case report demonstrates that reduction with contrast enema is a safe alternative to laparotomy in adults with cystic fibrosis and confirmed intussusception.

\section{Learning points}

- Patients with cystic fibrosis have an increased risk of developing intussusception.

- Young adults with intussusception and no sign of perforation or ischaemia can safely be managed with contrast enema. 


\section{Images in...}

Competing interests None declared.

Patient consent Obtained.

Provenance and peer review Not commissioned; externally peer reviewed.
2 Chaun H. Colonic disorders in adult cystic fibrosis. Can J Gastroenterol 2001;15:586-90.

3 Applegate KE. Intussusception in children: evidence-based diagnosis and treatment. Pediatr Radiol 2009:39(Suppl 2):140-3.

\section{REFERENCES}

1 Kassir R, Debs T, Boutet C, et al. Intussusception of the Meckel's diverticulum within its own lumen: unknown complication. Int J Surg Case Rep 2015;10:111-14.

Copyright 2015 BMJ Publishing Group. All rights reserved. For permission to reuse any of this content visit http://group.bmj.com/group/rights-licensing/permissions.

BMJ Case Report Fellows may re-use this article for personal use and teaching without any further permission.

Become a Fellow of BMJ Case Reports today and you can:

- Submit as many cases as you like

- Enjoy fast sympathetic peer review and rapid publication of accepted articles

- Access all the published articles

- Re-use any of the published material for personal use and teaching without further permission

For information on Institutional Fellowships contact consortiasales@bmjgroup.com

Visit casereports.bmj.com for more articles like this and to become a Fellow 